\title{
AZ ARKHIMÉDÉSZ-FÉLE SPIRÁLIS VEZÉRVONALÚ FOGASKERÉK LEFEJTŐ MARÓFEJE PONTOSSÁGÁNAK NÖVELÉSE
}

\section{THE IMPROVEMENT OF THE PRECISION OF THE ARCHIMEDEAN SPIRAL TOOTHLINE GEAR CUTTING MILL}

\author{
Gyéresi Hunor András, ${ }^{1}$ Cristea Luciana, ${ }^{2}$ Máté Márton ${ }^{3}$ \\ ${ }^{1}$ Brassói Transilvania Egyetem, Doktori Iskola, Brassó, Románia, hunor.gyeresi@unitbv.ro \\ ${ }^{2}$ Brassói Transilvania Egyetem, Terméktervezési és Környezetmérnöki Kar, Brassó, Románia, \\ lcristea@unitbv.ro \\ ${ }^{3}$ Sapientia EMTE, Marosvásárhelyi Kar, Gépészmérnöki Tanszék. Marosvásárhely, Románia, \\ mmate@ms.sapientia.ro
}

\begin{abstract}
The precision of gears has a major influence on the quality of the transmission. If the gear cannot be finished by grinding, the precision of the generating tool becomes essential. Archimedean spiral toothline cylindrical gears are obtained by reciprocate meshing using a milling cutter built up by individual cutters, organized in groups. The profiles of edges must be realized with a minimal profile error. In order to ensure the quality and the precision of the meshed tooth surface, and also the profile constancy after re-sharpening, relief faces must be realized by a grinding relieving operation. A secondary effect of the kinematics of relieving end the spatial extent of the grinding wheel a post undercut results and this produces an inevitable profile error. The present paper discusses a possible grinding wheel setting that produces a maximum theoretical profile error under $1 \mu \mathrm{m}$ along the whole re-sharpening reserve of the cutter. The proposed setting can be realized on a classical relieving lathe.
\end{abstract}

Keywords: gear cutting, milling head, relieving, profile error.

\section{Összefoglalás}

A fogaskerék-hajtóművek hajtásminőségét jelentősen befolyásolja a fogazat pontossága. Amennyiben a köszörülés nem lehetséges, a lefejtő szerszám pontossága meghatározóvá válik. Az Arkhimédész-féle spirális fogirány-vonalú fogaskerekeket csoportkéses marófejjel munkálják végleges méretre és alakra. Így a késeket a lehető legkisebb profilhibával kell megmunkálnunk. A jó felületminőség és pontosság érdekében, a kötelező profiltartás mellett, a kések hátfelületét hátraköszörüléssel kell előállítani. A köszörükorong elmetszése miatt profilhiba keletkezik. Jelen cikk a kések hátraköszörülésének olyan korrekciós beállítására tesz javaslatot, amelynek következményeképpen a teljes újraélezési tartományon $1 \mu \mathrm{m}$ alatti lesz a maximális elméleti profilhiba. A művelet egy hagyományos hátraesztergapadon megvalósítható.

Kulcsszavak: fogaskerékgyártás, marófej, hátramunkálás, profilhiba.

\section{A marófej elvi felépítése}

Az Arkhimédész-féle spirális fogirányvonalú fogazatot egy olyan felülettel lehet származtatni, amelynek generáló görbéje egy, az evolvenskerekeket lefejtő fogasléc profiljával egyezik meg, vezérgörbéje pedig egy Arkhimédész-féle spirális [1, 2]. A kapcsolódó fogazatok felépítése Olivier első tételének megfelelő módon [3], egyetlen közös származtatófelülettel valósul meg. A lefejtést, ennek megfelelően, ugyanazzal a szerszámmal 
végezzük el. A virtuális fogasléc a marófej forgásakor, a spirális effektus következményeként jön létre, és sugárirányban halad. A kinematikai vázlatot az 1. ábrán szemléltettük. Profilja szabványos $\alpha_{0}=20^{\circ}$-os profilszögü. A marófej a $Z_{s}$ számú késcsoportba rendezett, csoportonként $Z_{k}$ betétkést tartalmaz. Egy csoporton belüli kések ugyanazt a fogárkot, az egymás utáni csoportok pedig egymást követő fogárkokat munkálnak meg.

A marófejbe rögzített kések müködő csúcs- és oldalhátszögei folyamatosan változnak. A kések konstruktív geometriáját úgy kell kialakítani, hogy a megmunkálás alatt ezek megfelelő értéken maradjanak [5, 6].

\section{A szerszám hátfelületeinek matema- tikai modellje}

\subsection{A modell célja}

A hátraköszörülés matematikai modelljének célja a köszörütárcsa és a betétkés relatív kinematikájának leírása. Ennek alapján összefüggéseket nyerünk a beállítás paraméterei és a keletkező konstruktív hátszögértékek között, megkapjuk a hátfelület egyenleteit, amiből az újraélezés során

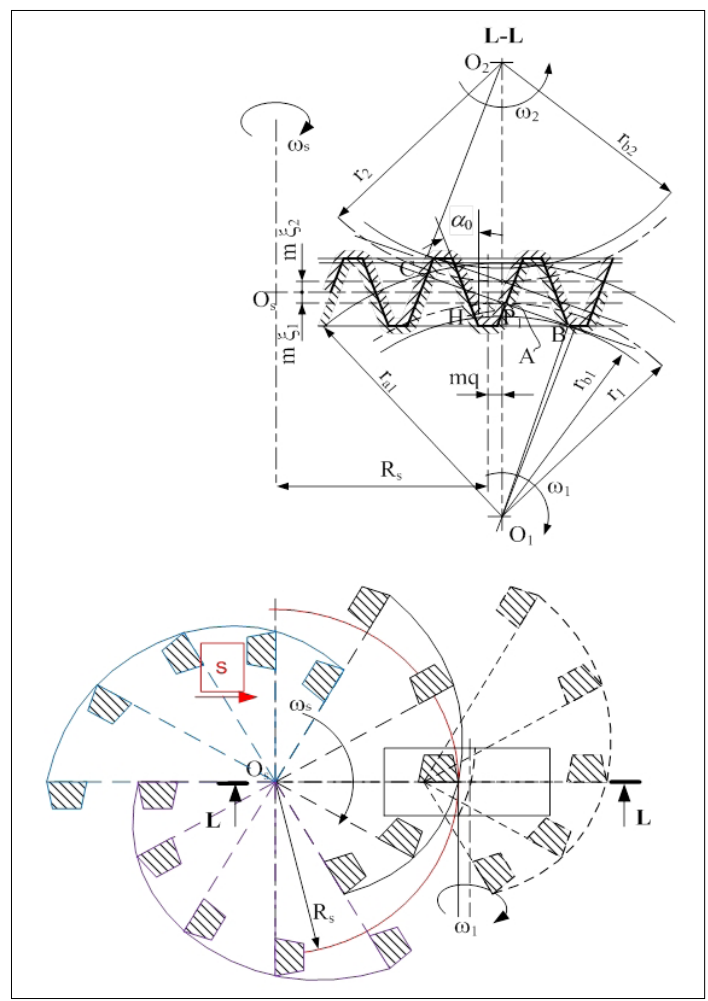

1. ábra. A virtuális fogasléc kialakulása [4] keletkező új él geometriáját írhatjuk fel, és ezáltal információt nyerünk a lehetséges profilhibáról. A modell általános, egyaránt alkalmazható a konvex és a konkáv oldalt megmunkáló késekre.

\subsection{Jelölések}

A modellben a következő jelöléseket használjuk: $m_{n}$ - normálmodul, [mm];

$\alpha_{0}$ - normál kapcsolószög, a kés profilszöge, [ [];

$u$ - a kés élparamétere, [mm];

$u_{k}$ - a köszörükorong generátorparamétere, [mm];

$\xi$ - a köszörükorong szögparamétere, [ [];

$\varphi$ - a marófej elfordulási szöge, $\left[^{\circ}\right]$;

$R_{s}$ - a marófej referenciasugara, [mm];

$R_{k}$ - a köszörükorong referenciasugara, [mm];

$R_{u k}$ - a köszörükorong $u_{k}$ paraméternek megfelelő sugara, [mm];

$\psi$ - a köszörűkorong félkúpszöge, $\left[^{\circ}\right]$;

$\alpha_{\text {knstr }}$ - konstruktív hátszög, [ ${ }^{\circ}$ ];

$\lambda$ - a hátramunkálás vezérspirálisának paramétere, $[\mathrm{mm} / \mathrm{rad}]$.

A köszörűkorong és a hátramunkálásnak alávetett betétkés relatív helyzetét a 2 . ábrán szemléltetjük. Az ábrán feltüntetett koordináta-rendszereket a következő módon értelmezzük:

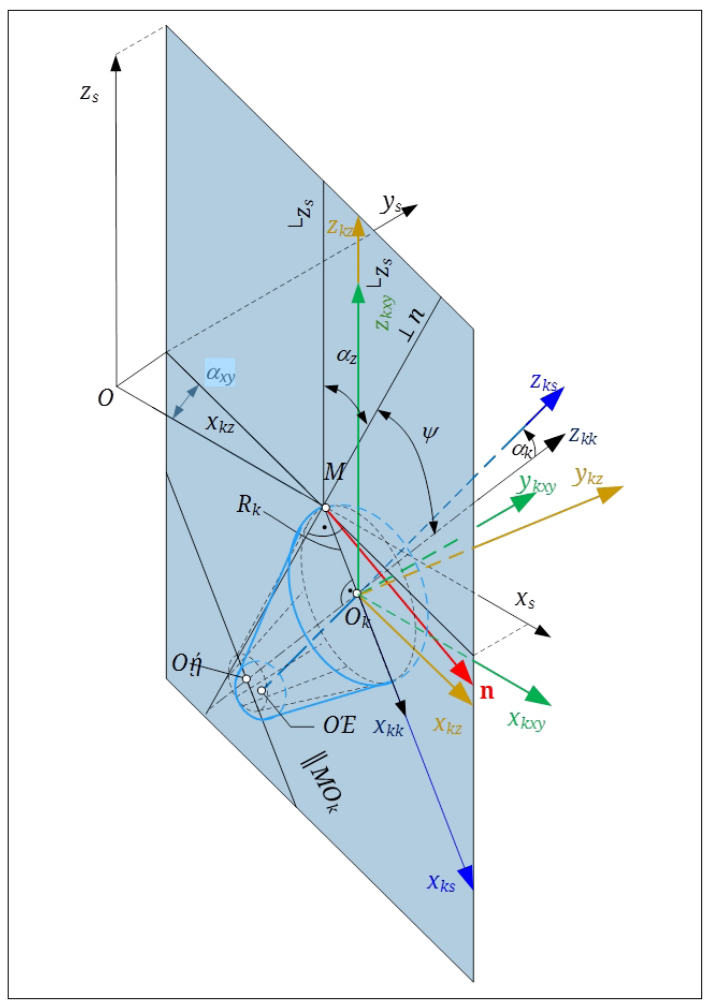

2. ábra. A köszörüszerszám és a munkadarab relatív helyzetét meghatározó koordináta-rendszerek 
$X_{s} Y_{s} Z_{s} \quad$ - a marófej koordináta-rendszere;

$X_{k s} Y_{k s} Z_{k s}$ - a köszörükoronghoz csatolt rendszer; $X_{0} Y_{0} Z_{0} \equiv X_{s} Y_{s} Z_{s}-$ az állványhoz kapcsolt rendszer, mellyel a gyártókészülék rendszere a mozgás kezdetekor egybeesik;

$X_{k k} Y_{k k} Z_{k k}-$ a köszörükorong végleges, kidöntött helyzete;

$X_{k z} Y_{k z} Z_{k z}$ - a köszörükorong origóját meghatározó kezdeti segédrendszer, melynek (zy) síkja tartalmazza a választott $M$-pontbeli felületi normálist;

$X_{k x y} Y_{k x y} Z_{k x y}$ - a kiforgatott segédkoordináta-rendszer (párhuzamos az $X_{s} Y_{s} Z_{s}$ koordináta-rendszerrel).

\subsection{A szerszám hátfelületeinek egyenletei}

A kések élei a marófej tengelysíkjába illeszkednek. Bármelyik kést olyan helyzetbe forgathatunk, a $Z_{1}$ tengely körüli elforgatással, hogy az él az $X_{1} Z_{1}$ síkba illeszkedjen. Megjegyezzük, hogy bár a késfejben a kések különböző elhelyezésüek, a hátramunkálásra mindegyiknek ugyanaz a forgástengelyhez viszonyított beállítási sugara. A hátramunkálás kinematikája alapján [7, 8] a hátfelületek parametrikus egyenletei a következők:

$$
\left\{\begin{array}{l}
X_{1}(u, \varphi)=\left(R_{s}+j\left(\frac{\pi m_{n}}{4}+u \operatorname{tg} \alpha_{0}\right)+\lambda \varphi\right) \cos \varphi \\
Y_{1}(u, \varphi)=\left(R_{s}+j\left(\frac{\pi m_{n}}{4}+u \operatorname{tg} \alpha_{0}\right)+\lambda \varphi\right) \sin \varphi \\
Z_{1}(u, \varphi)=u, j \in\{-1 ; 1\}
\end{array}\right.
$$

A felület tetszőleges pontjában a normálvektor

$$
\boldsymbol{n}(u, \varphi)=\left(\begin{array}{c}
-\lambda \sin \varphi-X_{1}(u, \varphi) \\
-\lambda \cos \varphi+Y_{1}(u, \varphi) \\
j \operatorname{tg} \alpha_{0}\left(R_{s}+j\left(\frac{\pi m_{n}}{4}+\lambda \varphi\right)\right)
\end{array}\right)
$$

\section{A hátraköszörülés geometriai modellje}

A hátraköszörülési műveletet klasszikus hátraesztergapadra tervezzük. A marófej betétkéseit olyan készülékbe helyezzük, mely ugyanazt a tájolást biztosítja, mint amit a marófejben kapnak. A köszörűszerszám megfelelő tájolásához a köszörüegységet egy olyan tartóra építjük, amely megengedi a két független tengely szerinti bedöntést.

A köszörűkő névleges átmérőjét a fogmagasság felénél értelmezzük, vagyis az $R_{k}$ sugárértéket az $u_{k}$ paraméter nulla értékének helyén vesszük fel.

$\mathrm{Az}$ elméleti hátfelületnek az élen illeszkedő $\mathrm{M}$ pontját jelöljük ki. Ennek parametrikus koordinátái $u=0 ; \varphi=0$. Ez a pont a hibamentes egyenes vágóélszakasz referencia- és egyben felezőpontja.
A kijelölt M pontba felvesszük a $\Sigma_{\alpha}$ hátfelület $\mathbf{n}$ normálvektorát, majd felvesszük a rajta keresztülhaladó, az $O z_{s}$ tengellyel párhuzamos síkot, mely az $\left(x_{s} z_{s}\right)$ koordinátasíkkal az $\alpha_{x y}$ szöget zárja (az index arra a síkra utal, amelyikben a szög valós méretében mutatkozik.

Az $O_{k} x_{k x y} y_{k x z} z_{k x y}$ koordináta-rendszer tengelyei a gépágy, illetve az alaphelyzetben levő felület koordináta-rendszerének megfelelő tengelyeivel párhuzamosak, de ez a rendszer az $O_{s} x_{s} y_{s} z_{s}$-hez képest a $z$ tengely körül $-180^{\circ}$-kal el van forgatva.

A normálvektor síkjára irányított $O_{k} x_{k z} y_{k z} z_{k z}$ koordináta-rendszert az $O_{k} x_{k x y} y_{k x z} z_{k x y}$ rendszer $O_{k} z_{k x y}$ tengelye körüli - $\alpha_{x y}$ szöggel való elforgatása eredményeként kapjuk.

A továbbiakban a kúpos köszörüszerszám tengelyének beállítását az $\left(O_{k} x_{k z} z_{k z}\right)$ síkban vizsgáljuk (3. ábra).

A kúpfelületet úgy állítjuk be, hogy a generátora az $M$ pontban a $\left(\Sigma_{\alpha}\right)$ felületi érintősíkban, az $\mathbf{n}$ normálisra húzott merőlegessel egybeessen. Ez esetben az $x_{k k}$ és $x_{k z}$ tengelyek közötti szög az $\mathbf{n}$ normálvektor $\left(x_{s} y_{s}\right)$ síkkal bezárt $\alpha_{z}$ szögének és a kúp $\psi$ félszögének algebrai összege lesz:

$$
\alpha_{z}^{*}=\alpha_{z}+\psi
$$

Jelen esetben, amikor a kúp csúcsa az él csúcsa felé van irányítva, $\psi>0$, ellenkező esetben $\psi<0$. Az $y_{k z}$ és az $y_{k k}$ tengelyek egybeesnek, és a 3. ábrán feltüntetett síkra értelemszerűen merőlegesek.

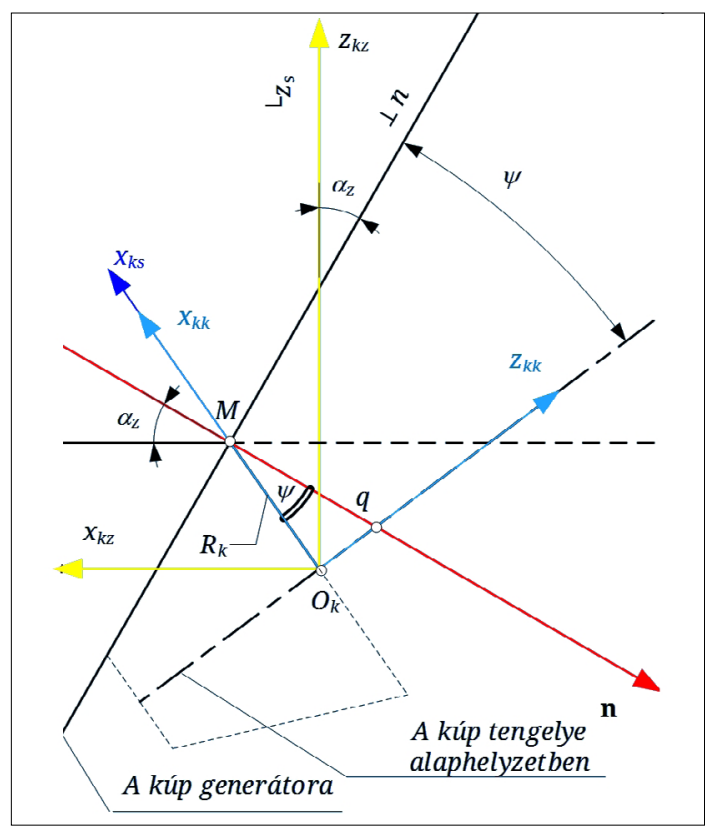

3. ábra. A köszörüszerszám kezdeti beállítása 
Belátható, hogy az $O_{k} x_{k k} y_{k k} z_{k k}$ koordináta-rendszer az $O_{k} x_{k z} y_{k z} z_{k z}$ koordináta-rendszernek $y_{k z}$ tengely körüli, $-\alpha_{z}^{*}$ szöggel való elforgatásával jön létre.

A köszörüszerszám dolgozó helyzetbe állított $O_{k} x_{k s} y_{k s} z_{k s}$ koordináta-rendszere a kezdeti alapbeállítás $O_{k} x_{k k} y_{k k} z_{k k}$ koordináta-rendszerének az $x_{k k} \equiv x_{k s}$ tengely körüli elforgatásával, azaz a köszörűkő „kidöntésével” jön létre. Ennek a kidöntésnek az oka az, hogy az él menti normálvektorok közül csak az $M$ referenciapontbeli halad át a forgástest tengelyén, ami a két felület kapcsolódásának alapfeltétele. A kidöntési szöget $\alpha_{k}$-val jelöljük. A 4. ábrán szemléltetjük, hogy az élcsúcsban és az éltőpontokban értelmezett normálvektorok tartóegyenesei az $M$ pontban értelmezett normálistól ellentétes irányban térnek el. Ezért az $x_{k k}$ tengely körüli kidöntés megőrzi a kapcsolódási feltételeket az él referenciapontjában, és a lehető legközelebb kerül a szélső pontokban a feltétel betartásához, azaz a szélső pontokban értelmezett normálisok tartóegyenesei a lehető legkisebb távolságra kerüljenek a köszörüszerszám forgástengelyétől.

A köszörűkorong palástfelületének parametrikus egyenletei, a 2. ábra alapján, a következők:

$$
\begin{gathered}
\boldsymbol{r}_{k s}\left(u_{k}, \xi\right)=\left(\begin{array}{c}
-R_{u k} \cos \xi \\
-R_{u k} \sin \xi \\
u_{k}
\end{array}\right) \\
R_{u k}=R_{k}-u_{k} \operatorname{tg} \psi
\end{gathered}
$$

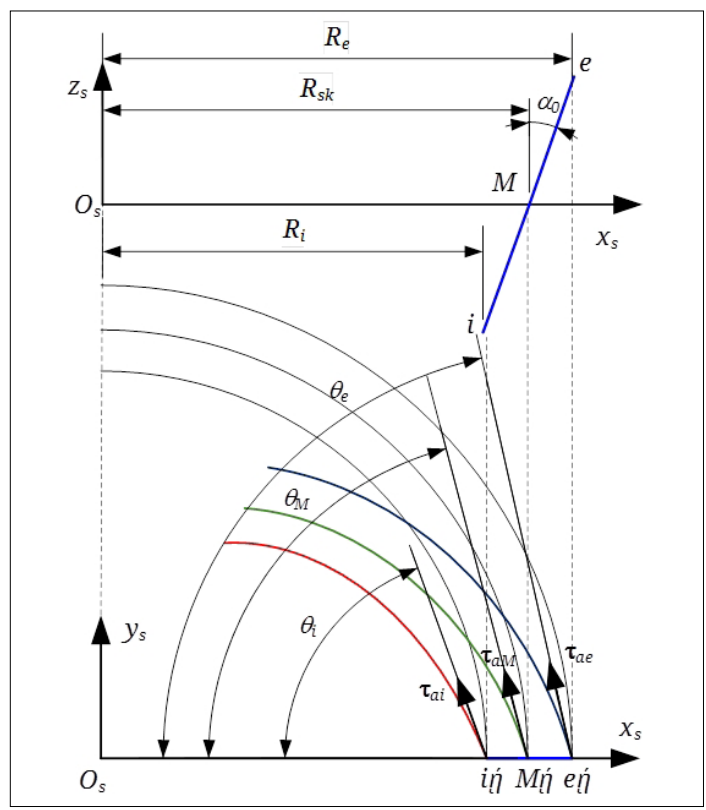

4. ábra. A szerszám-hátfelület normálvektorának irányváltozása - vetületekben
A (4) parametrikus egyenletekben $R_{k}$ a köszörükorong névleges középsugara, $\psi$ a köszörükorong félkúpszöge, $u_{k}$ és $\xi$ a kúppalást egymástól független magasság-, illetve szögparaméterei. Az él hoszsza, mely az $u$ paraméter függvénye, megegyezik a köszörűkő generátorának hosszával.

A köszörükorong tengelyének hosszában mért $u_{k}$ paraméter és a vágóél magasságában mért $u$ paraméter között, abból a kezdeti elgondolásból, hogy a generátor hasznos szakasza egybeesik a vágóél hasznos szakaszával, a következő lineáris paraméter-kapcsolat következik:

$$
\frac{u_{k}}{\cos \psi}=\frac{u}{\cos \alpha_{0}}
$$

A normálvektor (2) koordinátáiból számítjuk ki a tartóegyenesének az $x_{k z} z_{k z}$ síkkal bezárt szögértékét:

$$
\alpha_{x y}=-\operatorname{arctg} \frac{\lambda}{R_{s}+\frac{\pi m_{n}}{4}}
$$

A (3) képletben szereplő $\alpha_{z}$ szög szintén a (2) parametrikus koordinátákból vezethető le, a vágóélpontoknak megfelelő $\varphi=0$ sajátos értékre:

$$
\alpha_{z}=-\operatorname{arctg}\left(\operatorname{tg} \alpha_{0} \cos \alpha_{x y}\right)
$$

A billentés során a köszörükő tengelye a $z_{k k}$ helyzetből a $z_{k z}$ helyzetbe kerül, ami az $x_{k k} y_{k k} z_{k k}$ koordináta-rendszer $x_{k k} \equiv x_{k s}$ tengely körüli elforgatását jelenti.

Az elforgatás $\alpha_{k}$ szögét abból a feltételből határozzuk meg, hogy a kibillentett tengelyhez minél közelebb illeszkedjen a fogtőben és a fogcsúcsban értelmezett normálvektorok tartóegyenese.

Értelmezzük a következő szögfüggvényt a fogmagasság paraméter függvényében:

$$
\operatorname{tg} \theta(u)=\frac{\lambda}{R_{s}+\frac{\pi m_{n}}{4}+u \operatorname{tg} \alpha_{0}}
$$

A számítások terjedelme miatt ezeket mellőzzük. Az $\alpha_{k}$ billentési szög értéke, a (8) függvény figyelembevételével

$$
\begin{aligned}
\operatorname{tg} \alpha_{k}= & \frac{R_{k}\left(\operatorname{tg} \theta\left(m_{n}\right)-\operatorname{tg} \theta\left(-m_{n}\right)\right) \cos \alpha_{z}}{2 m_{n}}- \\
& -\operatorname{tg} \alpha_{0} \sin \alpha_{x y} \cos \alpha_{z}
\end{aligned}
$$

A köszörüszerszám saját ( $\left.x_{k s} y_{k s} z_{k s}\right)$ koordinátarendszere és az $\left(x_{k x y} y_{k x y} z_{x k y}\right)$ segéd-koordinátarendszer közötti transzformációs mátrixot három szukcesszív forgatásból kapjuk:

$$
\boldsymbol{M}_{(k x y, k s)}=\boldsymbol{M}_{(k x y, k z)} \boldsymbol{M}_{(k z, k k)} \boldsymbol{M}_{(k k, k s)}
$$

A (10) transzformációs mátrix elemeit $m_{i j}, i, j \in \overline{1,3}$-mal jelöljük. A köszörűkő tájolását a 
(10) mátrixegyenletet meghatározó (3), (6), (7), (9) elforgatási szögek hagyományos hátramunkálópad használata esetében nem változtathatók, így ezek konstansokként fognak szerepelni a további egyenletekben.

A továbbiakban bemutatásra kerülő linearizált modell esetében a normál-egységvektor koordinátáit használjuk. A normálvektor, az (1) és (2) kifejezésekből a következő:

$$
\left\{\begin{array}{c}
n_{x}(\varphi)=R_{s}+\frac{m_{n} \pi}{4}+\lambda \varphi \\
n_{y}(\varphi)=-\lambda \\
n_{z}(\varphi)=-n_{x}(\varphi) \operatorname{tg} \alpha_{0} \\
l(\varphi)=\sqrt{\left(R_{s}+\frac{m_{n} \pi}{4}+\lambda \varphi\right)^{2}\left(1+\operatorname{tg}^{2} \alpha_{0}\right)+\lambda^{2}}
\end{array}\right.
$$

Ezzel a felület normál-egységvektorának koordinátái:

$$
e_{k}(\varphi)=\frac{n_{k}(\varphi)}{l(\varphi)}, k \in\{x ; y ; z\}
$$

\section{A burkolófelület egyenletei}

A hátramunkálás során a köszörüszerszám radiális irányú mozgást végez, miközben a késtartó készülék elfordul. A 2. ábrán szemléltetett geometriai modellben ezt az $x_{k x y} y_{k x y} z_{k x y}$ koordináta-rendszernek az $x_{s} y_{s} z_{s}$ koordináta-rendszerhez viszonyított elfordulása és sugárirányú közeledése fejezi ki.

A gépágy rendszerében a köszörükorong középpontjának az elmozdulása és a késtartó készülék elfordulása egyenesen arányos.

Ielöliük a köszörűkorong középpontját $\boldsymbol{r}_{0 k}=\left(\begin{array}{llll}x_{0 k} & y_{0 k} & z_{0 k}\end{array}\right)^{T}$ helyvektorral, amikor a késtartó elfordulása $\varphi=0$, az elemi elmozdulás pedig legyen $\delta=\left(\begin{array}{lll}\delta_{x} & \delta_{y} & \delta_{z}\end{array}\right)^{T}$. A köszörü középpontiának a pályája a gépágy rendszerében, $\varphi \in\left[\varphi_{0} ; \varphi_{v}\right]$ esetén:

$$
\boldsymbol{r}_{0}(\varphi)=\boldsymbol{r}_{0 k}+\left(\varphi-\varphi_{0}\right) \boldsymbol{\delta}
$$

Mivel az $x_{k x y} y_{k x y} z_{k x y}$ és a gépágy koordináta-rendszerének a tengelyei párhuzamosak, a köszörükő palástfelszínének parametrikus egyenlete a gépágy rendszerében a következő:

$\boldsymbol{r}_{0 p}\left(\varphi, u_{k}, \xi\right)=\boldsymbol{r}_{0 k}+\boldsymbol{r}_{k x y}\left(u_{k}, \xi\right)+\left(\varphi-\varphi_{0}\right) \boldsymbol{\delta}$

A marófej koordináta-rendszerében az előbbi felületsereg egyenlete:

$$
\boldsymbol{r}_{s}\left(\varphi, u_{k}, \xi\right)=\boldsymbol{M}_{s, 0}\left(\boldsymbol{r}_{0}+\boldsymbol{r}_{k x y}\left(u_{k}, \xi\right)+\left(\varphi-\varphi_{0}\right) \boldsymbol{\delta}\right)
$$

ahol:

$$
\boldsymbol{M}_{s, 0}=\left(\begin{array}{ccc}
\cos \varphi & -\sin \varphi & 0 \\
\sin \varphi & \cos \varphi & 0 \\
0 & 0 & 1
\end{array}\right)
$$

$$
\boldsymbol{r}_{k x y}\left(u_{k}, \xi\right)=\boldsymbol{M}_{(k x y, k s)} \boldsymbol{r}_{k s}\left(u_{k}, \xi\right)
$$

A 2. ábrának megfelelően felírjuk a köszörükorong középpontjának kezdeti és végső helyzetvektorát:

$$
r_{0}^{\langle q\rangle}=\left(\begin{array}{c}
R_{s}+\frac{m_{n} \pi}{4}+\lambda \varphi_{q}+e_{x}\left(\varphi_{q}\right) R_{k x y}^{*} \\
e_{y}\left(\varphi_{q}\right) R_{k x y}^{*} \\
e_{z}\left(\varphi_{q}\right) R_{k x y}^{*}+\Delta_{z}\left(\varphi_{q}\right)
\end{array}\right), q \in\{0 ; v\}
$$

ahol:

$$
\begin{aligned}
& R_{k x y}^{*}=R_{k} \frac{\cos \left(\alpha_{z 0}+\psi\right)}{\cos \alpha_{z 0}} \\
& \begin{aligned}
& \Delta_{z}(\varphi)= R_{k}\left[\operatorname{tg}\left(\alpha_{z}(\varphi)+\psi\right)-\operatorname{tg} \alpha_{z}(\varphi)\right] \\
& \cdot \cos \left(\alpha_{z}(\varphi)+\psi\right)
\end{aligned} \\
& \delta=\frac{r_{0}\left(\varphi_{v}\right)-r_{0}\left(\varphi_{0}\right)}{\varphi_{v}-\varphi_{0}}
\end{aligned}
$$

A burkoló hátfelület egyenletét a (15) vektor adja, a paraméterek közötti kapcsolat $\xi=\xi\left(u_{k}, \varphi\right)$ alakjával, amit a következő kifejezéssorozat segítségével írunk fel, a számítások mellőzésével:

$$
\begin{aligned}
& D_{x}=r_{0 k x}+m_{13} u_{k}+\left(\varphi-\varphi_{0}\right) \delta_{x}+\delta_{y} \\
& D_{y}=-r_{0 k y}-m_{23} u_{k}-\left(\varphi-\varphi_{0}\right) \delta_{y}+\delta_{x} \\
& A=R_{u k} \operatorname{tg} \psi \cos \alpha_{z}^{*} \sin \alpha_{k}-\delta_{z} \sin \alpha_{z}^{*}- \\
& \quad-\left(D_{x} \sin \alpha_{x y}+D_{y} \cos \alpha_{x y}\right) \cos \alpha_{z}^{*} \\
& B=-R_{u k} \operatorname{tg} \psi \sin \alpha_{z}^{*}-\delta_{z} \cos \alpha_{z}^{*} \sin \alpha_{k}- \\
& -D_{x}\left(\cos \alpha_{x y} \cos \alpha_{k}-\sin \alpha_{x y} \sin \alpha_{k} \sin \alpha_{z}^{*}\right) \\
& +D_{y}\left(\sin \alpha_{x y} \cos \alpha_{k}+\cos \alpha_{x y} \sin \alpha_{k} \sin \alpha_{z}^{*}\right) \\
& C= \\
& \quad \operatorname{tg} \psi\left[-D_{x}\left(\cos \alpha_{x y} \sin \alpha_{k}+\right.\right. \\
& \left.\quad+\sin \alpha_{x y} \cos \alpha_{k} \sin \alpha_{z}^{*}\right)+ \\
& \quad+D_{y}\left(\sin \alpha_{x y} \sin \alpha_{k}-\cos \alpha_{x y} \cos \alpha_{k} \sin \alpha_{z}^{*}\right)+ \\
& \left.\quad+\delta_{z} \cos \alpha_{z}^{*} \cos \alpha_{k}\right]
\end{aligned}
$$

A (22a...e) kifejezések mindegyike $u_{k}$ és $\varphi$ függvénye. Ezzel a paraméterek közötti kapcsolat a következő lesz:

$$
\operatorname{tg} \xi=\frac{A B \pm C \sqrt{A^{2}+B^{2}-C^{2}}}{C^{2}-B^{2}}
$$

A javasolt megmunkálási eljárás előírja a köszörűkő origójának mindhárom tengely mentén történő elmozdulását, viszont a hagyományos hátramunkálópad ebből csak kettőt tesz lehetővé. Emiatt korrekciót kell végeznünk. A mozgást egy olyan síkra értelmezzük át, amely tartalmazza a forgástengelyt és párhuzamos a gépágyhoz viszonyított mozgás pályaegyenesével. A tengelyen 
áthaladó, a pályával párhuzamos sík és az xy sík szöge a következő:

$$
\operatorname{tg} \varepsilon=\frac{\delta_{y}}{\delta_{x}}
$$

Ezzel a köszörűkő palástja által leírt, korrigált felületsereg-egyenlet a következő lesz:

$$
\begin{aligned}
& \boldsymbol{r}_{\varepsilon}=\boldsymbol{M}_{\varepsilon} \boldsymbol{M}_{s, 0}\left(\boldsymbol{r}_{0}+\boldsymbol{r}_{k x y}\left(u_{k}, \xi\right)+\left(\varphi-\varphi_{0}\right) \boldsymbol{\delta}\right) \\
& \boldsymbol{M}_{\varepsilon} \boldsymbol{M}_{s, 0}= \\
& =\left(\begin{array}{ccc}
\cos \varepsilon & -\sin \varepsilon & 0 \\
\sin \varepsilon & \cos \varepsilon & 0 \\
0 & 0 & 1
\end{array}\right)\left(\begin{array}{ccc}
\cos \varphi & -\sin \varphi & 0 \\
\sin \varphi & \cos \varphi & 0 \\
0 & 0 & 1
\end{array}\right) \\
& =\left(\begin{array}{ccc}
\cos \varphi & -\sin \varphi & 0 \\
\sin \varphi & \cos \varphi & 0 \\
0 & 0 & 1
\end{array}\right)\left(\begin{array}{ccc}
\cos \varepsilon & -\sin \varepsilon & 0 \\
\sin \varepsilon & \cos \varepsilon & 0 \\
0 & 0 & 1
\end{array}\right)
\end{aligned}
$$

A (26) egyenlet kifejtéséből:

$$
\begin{aligned}
& \boldsymbol{r}_{\varepsilon}=\boldsymbol{M}_{s, 0}\left(\boldsymbol{r}_{0 \varepsilon}+\boldsymbol{r}_{k x y \varepsilon}\left(u_{k}, \xi\right)+\left(\varphi-\varphi_{0}\right) \boldsymbol{\delta}_{\varepsilon}\right) \\
& \boldsymbol{r}_{0 \varepsilon}=\boldsymbol{M}_{\varepsilon} \boldsymbol{r}_{0} \\
& \boldsymbol{r}_{k x y \varepsilon}\left(u_{k}, \xi\right)=\boldsymbol{M}_{\varepsilon} \boldsymbol{r}_{k x y}\left(u_{k}, \xi\right) \\
& \boldsymbol{\delta}_{\varepsilon}=\boldsymbol{M}_{\varepsilon} \boldsymbol{\delta}=\left(\begin{array}{c}
\delta_{x \varepsilon} \\
0 \\
\delta_{z}
\end{array}\right)
\end{aligned}
$$

\section{A modell numerikus vizsgálata}

A matematikai modell során alkalmazott értékek a következők:

$$
\begin{array}{ll}
\alpha_{0}=20^{\circ} & \text { - egyezményes profilszög } \\
m_{n}=5 \mathrm{~mm} & \text { - normálmodul } \\
R_{s}=80 \mathrm{~mm} & \text { - késtartó készülék sugara } \\
R_{k}=80 \mathrm{~mm} & - \text { köszörükő középsugara } \\
\psi=-1^{\circ} & - \text { köszörűkő félkúpszöge } \\
\alpha_{k n s t r}=-4^{\circ} & \text { - előírt konstruktív hátszög } \\
\phi_{0}=0^{\circ} & \text { - újraélezési tartomány alsó határa } \\
\phi_{v}=10^{\circ} & \text { - újraélezési tartomány felső határa }
\end{array}
$$

$\mathrm{Az}$ 5. ábrán látható a köszörükő palástfelszínének egy-egy részlete a megmunkálás kezdeti, tetszőleges és végső állapotában. Az oldalhátfelületen pirossal tüntettük fel az újraélezések során kialakított vágóéleket, melyeket numerikus eljárással kerestünk meg.

A hátramunkálás sajátosságai következtében, a szerszám újrafenése után a vágóél sugárirányban elmozdul. A késeket a marófejben sugárirányban úgy állítjuk be, hogy a kezdetben kijelölt $M$ ponttal egybeessen az új vágóél karakterisztikus pontja. A hibát a sugárkorrekció elvégzése után mértük.

A konstruktív hátszög az élmagasság függvényében változó értéket mutat. Emellett az újraélezé-

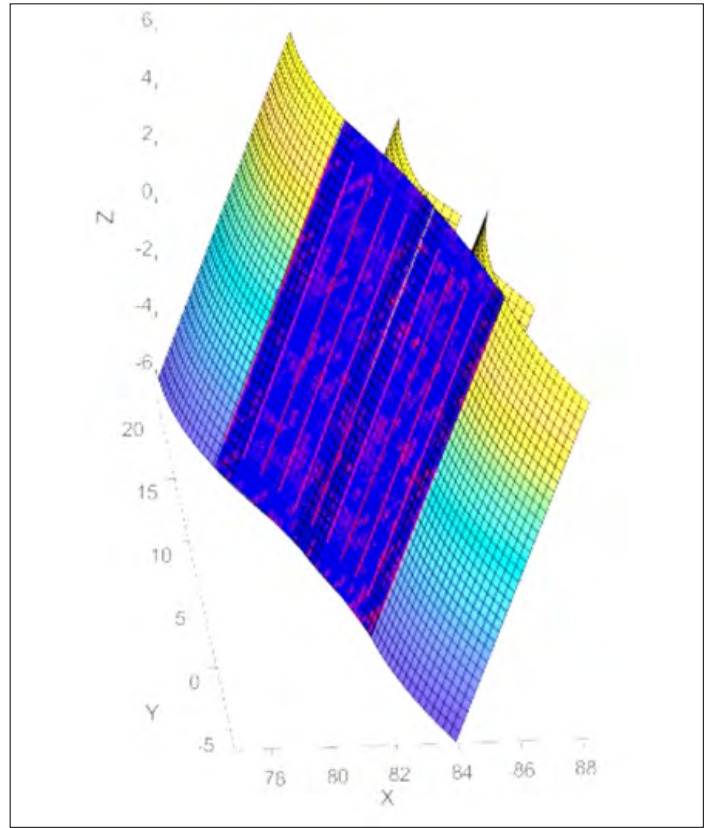

5. ábra. Az oldalhátfelület és a köszörükőpalást a megmunkálás különböző pillanataiban

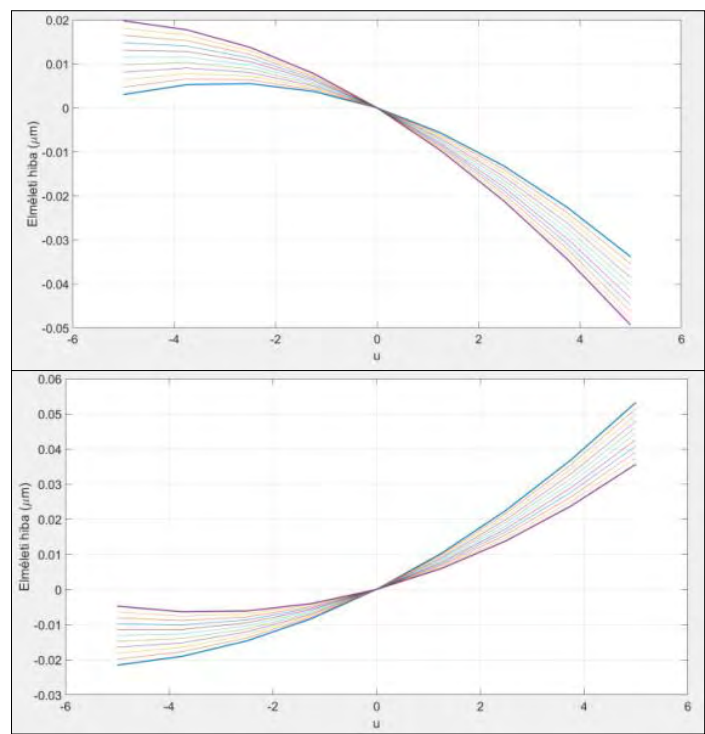

6. ábra. Az elméleti hiba változása az u fogmagasság-paraméter és az újraélezések függvényében belső(fent) és külső vágóél esetében

sek mértéke is, mind a külső, mind a belső vágóél esetében, befolyásolja a konstruktív oldalhátszöget ennek változása szögpercekben mérhető.

A numerikus vizsgálat során számított elméleti hiba abszolút értéke tizedmikrométer nagyságrendü. 


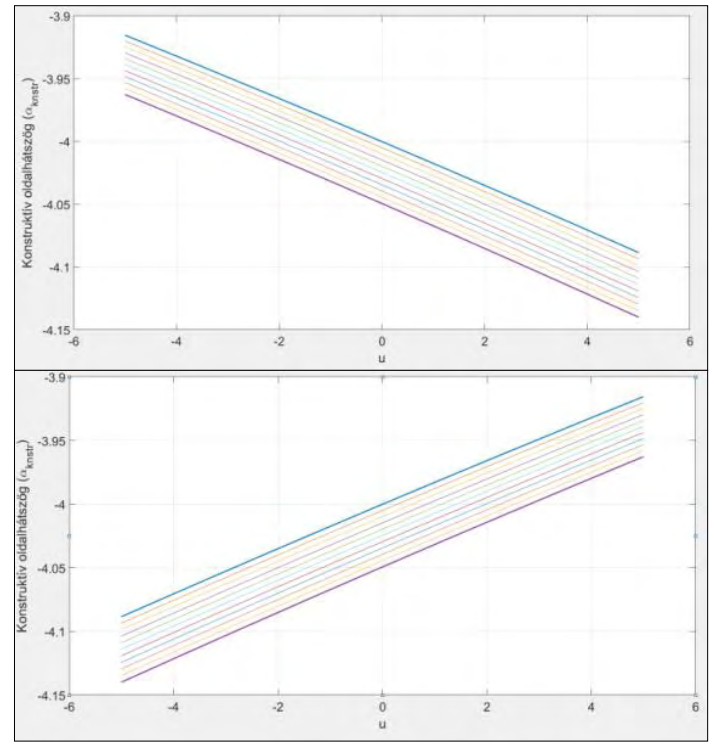

7. ábra. A konstruktív oldalhátszög változása az u fogmagasság és az újraélezések függvényében belső (fent) és külső vágóél esetében

\section{Következtetések}

A javasolt matematikai modell segítségével egy hagyományos hátramunkáló szerszámgépen költséghatékonyan elő tudunk állítani nagy pontosságú betétkéseket. A matematikai modell alkalmas a külső, illetve belső vágóélek oldalhátfelületeinek a megmunkálására. Az oldalhátszög és az élezési tartalékszögek nagy szögintervallumban változtathatóak úgy, hogy a maximális elméleti profilhiba mikrométer töredéke marad, illetve a konstruktív oldalhátszög változása szögpercekben mérhető.

\section{Szakirodalmi hivatkozások}

[1] Máté M.: Spirálfogazatú hengeres kerekek geometriája és gyártáselmélete. Kutatási beszámoló. MTA Domus Kuratórium, 2011. évi A2011061. számú pályázat, Budapest, 2011.1-18.

[2] Máté M.: Tangenciális lefejtéssel megvalósított Arkhimédész-féle spirál vezérgörbéjü fogazatok lefejtésének tanulmányozása. Kutatási beszámoló. A2-NJN-TOK-13-0009 azonosítójú, Neumann János kutatási beszámoló. 1-42.

[3] Litvin F. L.: A fogaskerék-kapcsolás elmélete. Budapest, Műszaki Könyvkiadó, 1972. 113-127.

[4] Máté M.: The micro-geometric model of the toothflanks of a cylindrical gear with archimedean spiral shaped toothline. In: $6^{\text {th }}$ International Scientific and Expert Conference TEAM 2014. 1-8.

[5] Gyéresi H. A.: A csigamarós fogaskerék-lefejtő gép kiegészitése az Arkhimédész-féle spirális fogirányvonalú fogaskerekek megmunkálásához. Államvizsga-dolgozat, Sapientia EMTE, 2016.

[6] Máté M., Gyéresi H. A.: About the Profile Constancy by Curved Teeth Cylindrical Gear's Cutter Head. In: MACRO-2015-International Conference on Recent Achievements in Mechatronics, Automation, Computer Science and Robotics. Tîrgu-Mures, Romania, March 6-7, 2015. Conference Proceedings. ISSN, ISSN-L: 2247-0948.13-24. https://doi.org/10.1515/macro-2015-0002

[7] Ábel J., Balajti Zs.: Szerszámél geometriai vizsgálatához szükséges feltétel, a Monge-tégla bijektív tartományának határfelülete. In: XXVII. Nemzetközi Gépészeti Konferencia, Nagyvárad, OGÉT, 2019. április 25-28., 22-26. .

[8] Balajti Zs., Dudás, I.: The Monge Theorem and Its Application in Engineering Practice. In: International Journal of Advanced Manufacturing Technology, 91/1-4. (2017) 739-749. https://doi.org/10.1007/s00170-016-9763-1 